\title{
Rootstocks for the new seedless table grape 'BRS Vitória' under tropical semi-arid conditions of São Francisco Valley
}

\section{Porta enxertos para a nova cultivar de uva de mesa sem sementes 'BRS Vitória' em condição tropical semiárida do Vale do São Francisco}

\author{
Patrícia Coelho de Souza Leão ${ }^{*} \mathbb{D}$, José Henrique Bernardino do Nascimento ${ }^{1} \mathbb{D}$, \\ Dayane Silva de Moraes ${ }^{1} \mathbb{D}$, Edimara Ribeiro de Souza' ${ }^{1}$
}

${ }^{1}$ Empresa Brasileira de Pesquisa Agropecuária/Embrapa, Embrapa Semiárido, Petrolina, PE, Brasil

*Corresponding author: patricia.leao@embrapa.br

Received in October 16, 2019 and approved in December 12, 2019

\begin{abstract}
'BRS Vitoria' is the most important Brazilian table grape cultivar in the domestic and foreign markets, standing out for the seedleness, pleasant flavor, high yield and mildew resistance. The aim of the present study was to determine the effect of the rootstock on the yield, production components, vigor, and physical and chemical characteristics of the 'BRS Vitória' grape under irrigation in the Brazilian semi-arid region. The experiment was conducted over eight consecutive production cycles in the period from 2015 to 2018 in a commercial area in the Senador Nilo Coelho project, Petrolina, PE. The treatments were represented by seven rootstocks: 'IAC 572', 'IAC 766', 'IAC 313', 'Harmony', 'SO4', 'Paulsen 1103', and 'Freedom', using a randomized block experimental design with four replications. The results were variable among production cycles, with significant effects of the rootstock in some cycles and/or in the overall mean of the cycles. The variables of pruning weight, sprouting, bud fertility, and titratable acidity were not affected by the rootstock in any of the production cycles evaluated in this study. 'Harmony' rootstock promoted greater berry mass and diameter but reduced the soluble solids content. Vines of 'BRS Vitória' showed moderate vigor, high bud fertility and yield, satisfactory characteristics of bunch and berry, sugars and acids content that meet the requirements of the most demanding markets in all the rootstocks evaluated in this study.
\end{abstract}

Index terms: Tropical viticulture; seedless grapes; yield; Vitis sp.

\section{RESUMO}

'BRS Vitória' é a mais importante cultivar brasileira de uvas de mesa, destacando-se pela ausência de sementes, sabor agradável, elevada produtividade e resisência ao míldio. O objetivo do presente estudo foi determinar o efeito do porta-enxerto no rendimento, componentes de produção, vigor, características físicas e físico químicas da uva 'BRS Vitória' sob irrigação no semi-árido brasileiro. O experimento foi realizado em oito ciclos consecutivos de produção, no período de 2015 a 2018, em uma área comercial no projeto Senador Nilo Coelho, Petrolina, PE. Os tratamentos foram representados por sete porta-enxertos: 'IAC 572', 'IAC 766', 'IAC 313', 'Harmony', 'SO4', ‘Paulsen 1103' e 'Freedom', em delineamento experimental de blocos ao acaso, com quatro repetições. Os resultados foram variáveis entre os ciclos de produção, com efeitos significativos do porta-enxerto em alguns ciclos, como também na média geral dos ciclos. As variáveis massa dos ramos após a poda, porcentagem de brotação, índice de fertilidade de gemas e acidez titulável não foram afetadas pelo portaenxerto em nenhum dos ciclos de produção avaliados neste estudo. O porta-enxerto 'Harmony' promoveu maior massa e diâmetro da baga mas reduziu o teor de sólidos solúveis das uvas. A cultivar BRS Vitória apresentou vigor moderado, elevada fertilidade de gemas e produtividade, características de cachos e bagas e teor de acúcares e ácidos que atendem as exigências dos mercados mais exigentes em todos os porta enxertos avaliados neste estudo.

Termos para indexação: Viticultura tropical; uvas sem sementes; produtividade; Vitis sp.

\section{INTRODUCTION}

Grafting grapevines using interspecific hybrid rootstocks of wild American species has become a common practice widely disseminated throughout the world since the second half of the nineteenth century when phylloxera was introduced in France and other countries of Europe, destroying the vineyards of Vitis vinifera, a highly susceptible specie (Whiting, 2012). There are currently estimated to be 70 to 80 rootstock classified in families according to their genealogy and their resistance to biotic and abiotic stresses (Ollat et al., 2016). 
In Brazil, grafting grapevines is a common practice, but the rootstocks used vary in affinity and compatibility between them, as well as on the interaction with the soil and climate depending on of each region (Vrisic; Pulko; Kocsis, 2015). In the Vale do São Francisco, Northeast of Brazil, grapevine rootstocks must combine characteristics such as vigor and resistance to pests, diseases, and nematodes and adapt to adverse soil conditions such as low fertility, salinity and drought (Leão; Silva, 2018).

Rootstock affected production components and grape quality of Kyoho (Chou; Li, 2014) and Summer Black table grapes (Jin et al., 2016). Agronomic behavior of grapevine under semi arid conditions affected bu rootstocks was studied under irrigation in Chile (Ibacache; Albornoz; Zurita-Silva, 2016) and India (Satisha et al., 2010).

The cultivar BRS Vitória was developed by the EMBRAPA breeding program (Maia et al., 2014) and it has shown in São Francisco Valley, high bud fertility, yield in the range 30 to 60 ton/ha/year, medium size bunches and berries, soluble solids content above $19{ }^{\circ}$ Brix, and titratable acidity between 0.6 to $0.8 \mathrm{~g}$ of tartaric acid 100 $\mathrm{mL}^{-1}$ (Leão; Lima, 2016). It is tolerant to downy mildew (Plasmopora viticola), reducing the amount of fungicides used by grape growers (Souza et al., 2018). The cultivated area of the Vale do São Francisco has increased rapidly in recent years but no information is available in the literature regarding the use of rootstocks and their effects on the agronomic response of the cultivar BRS Vitória.

Thus, the aim of the present study was to determine the effect of the rootstock on yield components and physical and chemical characteristics of grapes 'BRS Vitória' under irrigation in the São Francisco Valley, Northeastern of Brazil.

\section{MATERIAL AND METHODS}

The study was performed in a commercial vineyard in the Senador Nilo Coelho irrigation project (N8) in Petrolina, PE, Brazil (09 $09^{\circ} \mathrm{S}, 40^{\circ} 18^{\prime} \mathrm{W}$ and 369 $m$ AMSL). The experiment was set up in 2014 and the grapevines began yielding at approximately 10 months of age. Eight production cycles were performed in the period from 2015 to 2018, with two production cycles per year.

Climate in the region is BSwh', according to the Köppen classification, with the following annual mean values and deviations of the climate elements: air temperature, $26.2 \% \pm 0.9$; relative humidity, $64.4 \% \pm 5.5$; rainfall, $549.8 \pm 181.8 \mathrm{~mm}$; sunlight hours, $7.5 \pm 1.1$; solar radiation, $442.3 \pm 32.3 \mathrm{~W} \mathrm{~m}^{-2}$; Class A evaporation pan, 7.3 $\pm 0.6 \mathrm{~mm} \mathrm{day}^{-1}$; and air speed, $190.4 \pm 27.2 \mathrm{~km} \mathrm{day}^{-1}$. The mean monthly values of mean, maximum, and minimum air temperature $\left({ }^{\circ} \mathrm{C}\right)$, global solar radiation $\left(\mathrm{MJ} / \mathrm{m}^{2}\right)$, and rainfall $(\mathrm{mm})$ throughout the four years of the study were obtained from the Automatic Agricultural Weather Station at the Bebedouro Experimental Field, $34 \mathrm{~km}$ from the location of the experiment, and are shown in Figure 1.

The experiments were set up in a $3 \times 4 \mathrm{~m}$ spacing, with two plants in each plant hole, corresponding to a density of 1666 plants per hectare. The grapevines were trained in the horizontal trellis or pergola system and were drip irrigated. Plant development during the second and third production cycles was hurt by lack of uniform irrigation management within the plant rows and the occurrence of wood fungi that caused plant death and loss of plots, making evaluation and statistical analysis of some treatments impossible.

The architecture of the grapevine canopies was in a unilateral cordon, pruned in short canes or spurs with two to three buds in the first pruning and canes of intermediate length ( 5 buds) in the production pruning. The crop treatments, fertigation, and plant health control were performed by the grower according to the general recommendations for grape growing in the Vale do São Francisco (Leão; Silva, 2018).

The treatments corresponded to seven rootstock cultivars: 'IAC 313', 'IAC 766', 'IAC 572', 'Paulsen 1103', 'SO4', 'Harmony', and 'Freedom', chosen because they are the main rootstocks used in the Vale do São Francisco.

A randomized block experimental design was used with four replications, and the experimental plot consisted of six plants. Two plants were identified in the center of each plot, which were evaluated and from which grape bunches were harvested.

The following variables were evaluated in each production cycle: a) pruning weight - determined on a digital electronic balance (Ramuza DCR-15), in $\mathrm{kg}$ plant $^{-1} ;$ b) sprouting percentage $(\%)$ and bud fertility index - determined approximately twenty days after pruning during the phenological phase of budbreak before thinning of shoots, through counting the total number of buds, sprouts, and bunches on all the canes and spurs. According to the data collected, the values of budbreak and bud fertility were determined according to the following equations: sprouting $(\%)=$ no. of sprouts X $100 /$ no. of buds; fertility (index) $=$ no. of bunches / no. of sprouts; c) production and number of bunches per plant-determined during harvest through total weight of bunches on a digital electronic balance (Ramuza DCR-15), in kg plant ${ }^{-1}$; d) bunch weight: obtained by the ratio of the total weight of bunches $(\mathrm{g}) /$ number of bunches per plant, in grams (g); e) bunch length - determined in a sample of five 

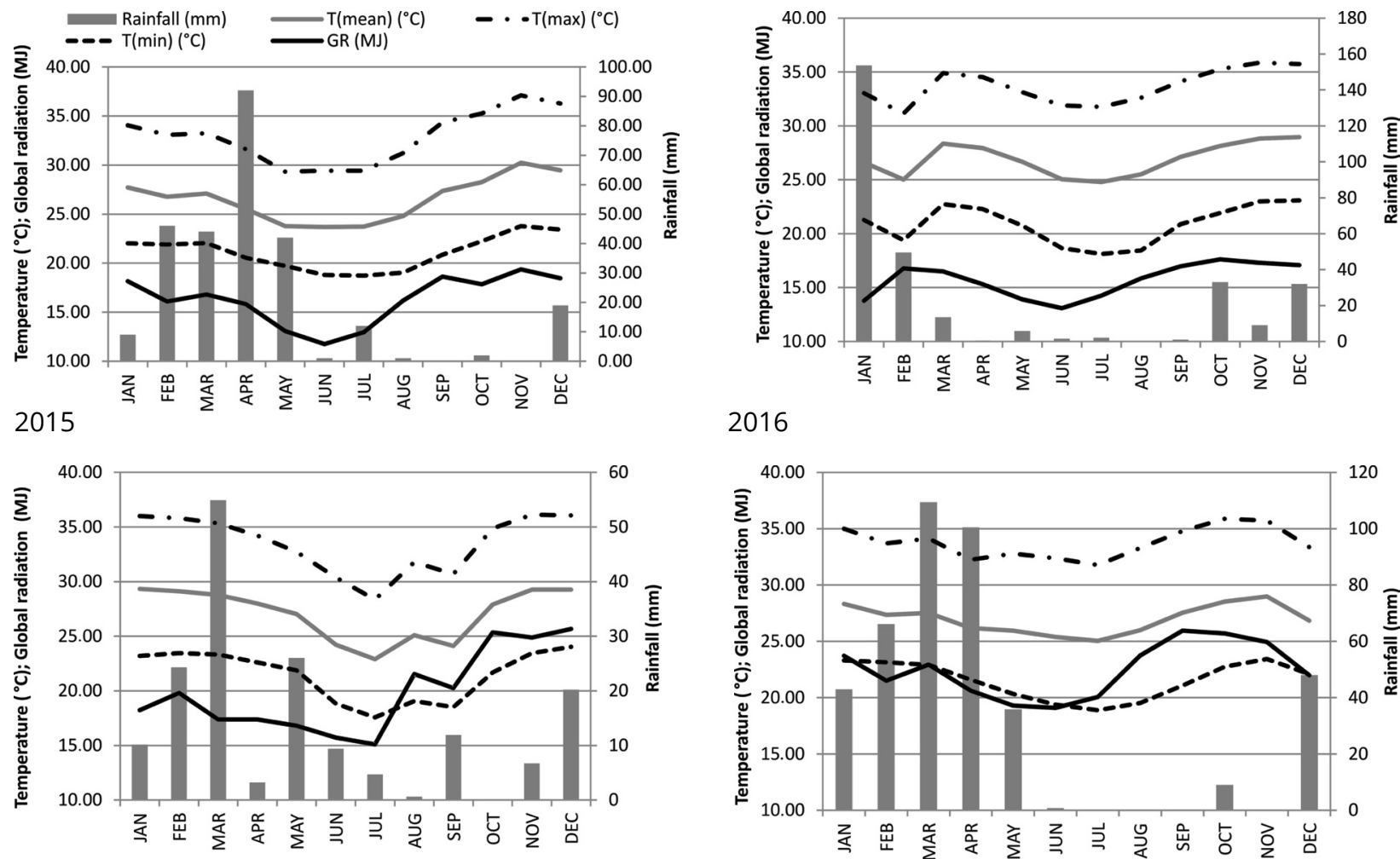

2016

2017

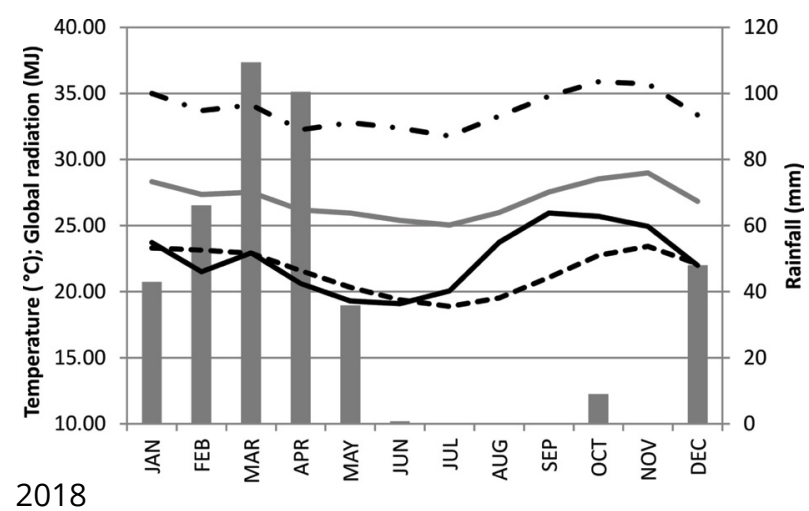

Figure 1: Seasonal rainfall variations ( $\mathrm{mm}$ ); average (Tmean), minimum (Tmin), and maximum (Tmax) temperature $\left({ }^{\circ} \mathrm{C}\right)$; and global radiation (GR) (MJ m²) from 2015 to 2018.

bunches per plot with the aid of a ruler, in centimeters (cm); f) berry weight - using a sample composed of 10 berries collected from five bunches per plot and weighed on a digital electronic balance, in grams (g); g) berry diameter - using the previous sample of berries, with the aid of a ruler, in millimeters $(\mathrm{mm})$; h) soluble solids content (SS) - obtained through the must extracted from 50 berries collected from the five bunches harvested in the field. Reading was made on a digital refractometer with automatic temperature adjustment (Atago, Digital Pocket Refractometer, model Pal-1) with values that ranged from 0 to $69^{\circ}$ Brix; i) titratable acidity (TA) - through dilution of $5 \mathrm{ml}$ of the grape pulp in $50 \mathrm{ml}$ distilled water, together with the $0.1 \mathrm{~N} \mathrm{NaOH}$ solution, using an automatic titrator, Metrohm brand (model 848 Titrino plus), presented in $\mathrm{g}$ of tartaric acid $100 \mathrm{~mL}^{-1}$ (AOAC, 2010).

The data for each production cycle and for the mean of all the cycles were assessed using the $\mathrm{F}$ test of analysis of variance, and the mean values were compared by the Tukey test at the level of 5\% probability using the SAS Studio ${ }^{\circledR}$ software.

\section{RESULTS AND DISCUSSION}

Significant effects of the rootstock were not observed for the variables of pruning weight, sprouting percentage, and bud fertility index throughout the production cycles or in the mean value of the cycles; thus, these data were not presented.

In this study, the rootstocks had an influence in some individual cases on production and on the physical and chemical characteristics of the bunches and berries of the 'BRS Vitória' grapevine, with significant effects in few production cycles and/or in the overall mean of the cycles (Tables 1 and 2). A response from the rootstock related to age of the plant was not observed as mentioned by Satisha et al. (2010) in 'Thompson Seedless' grapevines in India, in which significant results from the rootstock were observed only in young plants, but were not significant in adult plants.

Production per plant showed significant differences among rootstocks in the first (2015.1) and last production cycle (2018.2); however, in the mean value of the cycles, this effect was not significant (Table 1). The rootstock may 
affect grapevine yield because it affects different production components: bud fertility (number of bunches), fruit set, size and weight of the bunch and of the berry (Zhang et al., 2016). According to Bascunán-Godoy et al. (2017), the increase in yield of 'Red Globe' on the rootstocks 'Harmony' and 'Salt Creek' was correlated with the increase in light capture, greater leaf area, photosynthetic rate, light absorption capacity, production and mobilization of reserve carbohydrates on these rootstocks.
Therefore, superior production performance of 'BRS Vitória' on a particular rootstock or group of rootstocks was not observed. In contrast with the results obtained in this study, other authors found significant effects of the rootstock on yield and production components of other table grape cultivars, such as Flame Seedless, Thompson Seedless, Redglobe, and Sugraone, in semi-arid regions of Chile, Egypt, and India (Ibacache et al., 2016; Aly et al., 2015; Satisha et al., 2010).

Table 1: Mean values and coefficients of variation for production, number of bunches, and bunch weight and length of the cultivar BRS Vitória on different rootstocks over eight production cycles.

\begin{tabular}{|c|c|c|c|c|c|c|c|c|c|}
\hline \multirow{3}{*}{ Rootstocks } & \multicolumn{9}{|c|}{ Growing seasons } \\
\hline & \multicolumn{9}{|c|}{ Production $\left(\mathrm{Kg} \mathrm{plant}^{-1}\right)$} \\
\hline & 2015.1 & 2015.2 & 2016.1 & 2016.2 & 2017.1 & 2017.2 & 2018.1 & 2018.2 & Average \\
\hline Freedom & $7.92 a b$ & $11.95^{\mathrm{ns}}$ & ----- & $9.26^{\mathrm{ns}}$ & $22.36^{\mathrm{ns}}$ & $25.78^{\text {ns }}$ & $7.36^{\mathrm{ns}}$ & $12.72 a b$ & $14.99^{\text {ns }}$ \\
\hline Harmony & 7.12ab & 9.32 & $12.34^{\mathrm{ns}}$ & 11.30 & 24.67 & 32.73 & 9.39 & $15.47 \mathrm{a}$ & 16.75 \\
\hline IAC 313 & 7.83ab & 13.50 & ----- & 9.11 & 26.43 & 30.52 & 10.48 & $14.60 \mathrm{ab}$ & 17.61 \\
\hline IAC 572 & $4.47 b$ & 15.24 & 9.89 & 10.99 & 29.30 & 31.26 & 8.66 & $12.62 \mathrm{ab}$ & 16.78 \\
\hline IAC 766 & $18.01 a$ & 12.47 & 11.97 & 12.04 & 24.36 & 25.79 & 7.17 & $13.19 a b$ & 16.71 \\
\hline P1103 & $4.24 b$ & ----- & 13.77 & 12.51 & 27.67 & 28.29 & 10.83 & $13.30 \mathrm{ab}$ & 17.57 \\
\hline SO4 & $3.59 b$ & ----- & 13.43 & 8.15 & 27.39 & 28.31 & 9.33 & $9.96 \mathrm{~b}$ & 15.76 \\
\hline Mean & 7.60 & 12.50 & 12.28 & 10.48 & 26.03 & 28.95 & 9.03 & 15.35 & 16.60 \\
\hline \multirow[t]{2}{*}{ CV (\%) } & 18.56 & 31.79 & 16.35 & 17.97 & 19.55 & 22.85 & 9.03 & 13.12 & 7.20 \\
\hline & \multicolumn{9}{|c|}{ Number of bunches per plant } \\
\hline Freedom & 102.0ab & $64.33^{\text {ns }}$ & ---- & $46.88 b$ & $108.75^{\text {ns }}$ & $120.00^{\mathrm{ns}}$ & $36.13 a b$ & $127.50^{\text {ns }}$ & $87.91 b c$ \\
\hline Harmony & 81.67ab & 49.67 & $116.67^{\text {ns }}$ & $72.75 a$ & 136.13 & 128.38 & $45.88 \mathrm{ab}$ & 140.50 & $96.25 a b c$ \\
\hline IAC 313 & $96.67 a b$ & 59.67 & ----- & $47.88 b$ & 132.38 & 127.50 & $51.25 a b$ & 128.13 & 93.10abc \\
\hline IAC 572 & $66.00 \mathrm{ab}$ & 73.00 & 74.33 & $59.13 a b$ & 118.00 & 124.00 & $44.63 a b$ & 121.13 & $86.76 c$ \\
\hline IAC 766 & $158.33 a$ & 70.50 & 98.33 & $63.75 a b$ & 152.38 & 119.25 & $32.63 \mathrm{~b}$ & 118.50 & $101.22 \mathrm{ab}$ \\
\hline P1103 & 55.33ab & ----- & 126.33 & $61.38 a b$ & 141.50 & 142.13 & $54.13 a$ & 131.88 & $104.30 a$ \\
\hline SO4 & $45.00 \mathrm{~b}$ & ---- & 101.00 & $64.25 a b$ & 143.75 & 115.50 & $46.38 a b$ & 105.13 & $87.35 b c$ \\
\hline Mean & 86.43 & 63.43 & 103.33 & 59.43 & 133.27 & 125.25 & 44.43 & 124.68 & 93.84 \\
\hline \multirow[t]{2}{*}{ CV (\%) } & 20.01 & 24.98 & 22.28 & 16.14 & 16.52 & 18.00 & 19.59 & 23.09 & 6.59 \\
\hline & \multicolumn{9}{|c|}{ Bunch weight (g) } \\
\hline Freedom & $145.38^{\text {ns }}$ & $199.70^{\text {ns }}$ & ----- & $154.07 b$ & $277.82^{\text {ns }}$ & $288.89^{\text {ns }}$ & $185.83^{\text {ns }}$ & $212.11 a b$ & $211.94^{\mathrm{ns}}$ \\
\hline Harmony & 126.19 & 170.75 & $162.06^{\mathrm{ns}}$ & 174.83ab & 272.43 & 294.14 & 194.26 & $249.65 a b$ & 213.40 \\
\hline IAC 313 & 155.63 & 182.16 & ----- & $189.15 a$ & 244.63 & 265.75 & 178.50 & $251.27 a$ & 214.28 \\
\hline IAC 572 & 132.83 & 157.30 & 155.91 & 177.14ab & 245.25 & 318.70 & 162.54 & $222.56 a b$ & 201.65 \\
\hline IAC 766 & 155.49 & 193.64 & 160.58 & 186.58ab & 247.85 & 271.00 & 179.22 & 228.49ab & 208.64 \\
\hline P1103 & 120.71 & ----- & 165.99 & $171.15 a b$ & 260.82 & 252.28 & 164.32 & 183.46ab & 191.89 \\
\hline
\end{tabular}


Table 1: Continuation.

\begin{tabular}{cccccccccc}
\hline & \multicolumn{7}{c}{ Growing seasons } \\
\cline { 2 - 10 } Rootstocks & \multicolumn{7}{c}{ Bunch weight (g) } \\
\cline { 2 - 10 } & 2015.1 & 2015.2 & 2016.1 & 2016.2 & 2017.1 & 2017.2 & 2018.1 & 2018.2 & Average \\
\hline SO4 & 93.57 & ----- & 143.34 & $167.21 \mathrm{ab}$ & 256.66 & 283.63 & 163.99 & $197.57 \mathrm{~b}$ & 191.62 \\
Mean & 133.25 & 180.71 & 157.57 & 174.30 & 257.92 & 282.06 & 175.52 & 220.73 & 204.77 \\
CV (\%) & 16.98 & 11.75 & 14.07 & 8.27 & & 10.94 & 10.47 & 13.12 & 5.89 \\
\hline & & \multicolumn{7}{c}{ Bunch length (cm) } \\
\hline Freedom & $12.68 \mathrm{ab}$ & $13.51^{\text {ns }}$ & ----- & $13.75^{\text {ns }}$ & $19.40^{\text {ns }}$ & $19.46^{3}$ & $10.93^{\text {ns }}$ & $17.23^{\text {ns }}$ & $15.48 \mathrm{a}$ \\
Harmony & $12.35 \mathrm{ab}$ & 12.23 & $11.36^{\text {ns }}$ & 13.38 & 18.29 & 18.95 & 10.47 & 18.48 & $14.76 \mathrm{ab}$ \\
IAC 313 & $12.77 \mathrm{ab}$ & 11.88 & ---- & 14.36 & 17.18 & 18.53 & 10.26 & 17.70 & $14.86 \mathrm{ab}$ \\
IAC 572 & $13.18 \mathrm{ab}$ & 12.42 & 11.19 & 13.07 & 18.17 & 21.14 & 11.27 & 17.90 & $15.07 \mathrm{ab}$ \\
IAC 766 & $14.15 \mathrm{a}$ & 13.09 & 10.73 & 14.16 & 17.29 & 19.04 & 11.32 & 18.48 & $15.07 \mathrm{ab}$ \\
P1103 & $10.94 \mathrm{~b}$ & ----- & 11.04 & 12.77 & 17.53 & 17.75 & 10.22 & 16.55 & $14.13 \mathrm{~b}$ \\
SO4 & $10.65 \mathrm{~b}$ & ----- & 10.04 & 11.83 & 18.17 & 17.89 & 10.23 & 16.60 & $13.94 \mathrm{~b}$ \\
Mean & 12.39 & 12.63 & 10.87 & 13.33 & 18.00 & 18.96 & 10.67 & 17.56 & 14.76 \\
CV (\%) & 8.99 & 9.73 & 7.22 & 13.09 & 5.74 & & 6.88 & 6.39 & 3.41 \\
\hline
\end{tabular}

${ }^{1}$ Mean values followed by the same lowercase letter in the column do not differ by the Tukey test at $5 \%$ probability; ${ }^{2}$ ns: not significant; ${ }^{3}$ analysis of variance was not performed because the data did not exhibit normal distribution.

The mean production obtained was $16.6 \mathrm{~kg} \mathrm{plant}^{-1}$, which corresponded to an estimated mean yield of 27.7 ton $\mathrm{ha}^{-1}$ per cycle, higher than that mentioned by Maia et al. (2014) from 16 to 24 ton ha ${ }^{-1}$ for 'BRS Vitória' in tropical regions of Brazil. Although significant statistical differences were not observed among rootstocks, the mean estimated yield varied from 25 ton $\mathrm{ha}^{-1}$ in the rootstock 'Freedom' up to 29 ton ha $^{-1}$ per production cycle in the rootstocks 'IAC 313 ' and 'Paulsen 1103', i.e., a mean increase of 4 ton ha' ${ }^{-1}$, corresponding to an increase of $14 \%$ in yield across these rootstocks. The rootstock 'Paulsen 1103' promoted an increase in yield in the cultivar Crimson Seedless in Minas Gerais (Feldberg; Regina; Dias, 2007), a rootstock that is recognized for its high drought resistance and recommended for use in semi-arid conditions with water restriction because of its greater water use efficiency (Kondouras et al., 2008).

The number of bunches was affected by the rootstocks in three production cycles $(2015.1,2016.2$, and 2018.1) and also in the overall mean of the cycles. 'Paulsen 1103' stood out with 101 bunches per plant, compared to 'SO4', 'IAC 572', and 'Freedom', in which 87 bunches per plant were obtained, though it did not differ from the rootstocks 'IAC 766', 'Harmony', and 'IAC 313'. 'Paulsen 1103' also increased the number of bunches of the cultivar Sugraone compared to ' 420 A' in the Vale do São Francisco (Leão; Brandão; Gonçalves, 2011). This result explains the tendency toward greater production also observed over 'Paulsen 1103' and 'IAC 313', since, according to Ibacache, Albornoz and Zurita-Silva, (2016), the number of bunches resulted in the greatest contribution (from $59 \%$ to $82 \%$ ) to the variance in yield of 'Flame Seedless', 'Thompson Seedless', and 'Red Globe' on different rootstocks. However, yield differences observed among grapevine rootstocks are also a consequence of their influence on berry weight and number of berries per bunch (Paranychianakis et al., 2004).

The variations observed in production and number of bunches among production cycles may be the consequence of inter and intra-annual climate variations observed over the study (Figure 1), which may affect floral and bud fertility differentiation, causing common variations in production in consecutive crop seasons (Leão et al., 2017).

The bunch weight from the grapevines grafted on 'IAC 313' was greater than in 'Freedom' in 2016.2 and 'SO4' in 2018.2, but this effect did not result in significant differences in the overall mean of the cycles, whose values ranged from $192 \mathrm{~g}$ ('SO4' and 'Paulsen 1103 ') to $214 \mathrm{~g}$ ('IAC 313') (Table 2). The mean bunch 
weight regardless of the rootstock used was near the values observed for 'BRS Vitória' in this same region (Leão; Lima, 2016).

The rootstock did not affect berry weight and diameter over the production cycles, and bunch length differed among rootstocks only in the 2015.1 cycle, and soluble solids content in 2017.2. In contrast, a different response of the 'BRS Vitória' grapevines among rootstocks were observed in the overall mean of the cycles in bunch lenght, berry weight and berry diameter with the rootstock 'Freedom' increasing bunch length, and 'Harmony', showing higher berry weight and diameter, compared to 'Paulsen 1103' and 'SO4' (Table 2). 'Freedom' and 'Harmony' have parents in common as they are the results of the cross between 'Dog Ridge' (Vitis champinni) $\times$ 'Courdec 1613' (Christensen et al., 2003). Larger bunch and berry size and weight observed in 'Freedom' can be explained by the lower mean number of bunches on this rootstock compared to 'Paulsen 1103', which reduces competition among the berries for photoassimilates. In addition, the rootstock 'Freedom' favors uptake of $\mathrm{N}, \mathrm{P}$, and $\mathrm{K}$ and induces high vigor to the canopy (Christensen et al., 2003), which may have contributed to a reduction in the number of bunches but an increase in fruit size and weight.

The rootstock 'Harmony', in spite of having parents in common with 'Freedom', is recognized in California because it induces lower vigor to the canopy and also reduces uptake of nitrogen (Christensen et al., 2003). In this study, the rootstock 'Harmony', together with 'IAC 766' and 'IAC 313', favored both an increase in the number of bunches and an increase in berry weight and diameter. Nevertheless, among them, the rootstock 'Harmony' stands out because it increased berry weight and diameter in relation to the rootstocks 'Paulsen 1103', 'IAC 572', and 'SO4'.

Table 2: Mean values and coefficients of variation for berry weight and diameter, soluble solids content, and titratable acidity of 'BRS Vitória' grapes on different rootstocks over eight production cycles.

\begin{tabular}{|c|c|c|c|c|c|c|c|c|c|}
\hline \multirow{3}{*}{ Rootstocks } & \multicolumn{9}{|c|}{ Growing seasons } \\
\hline & \multicolumn{9}{|c|}{ Berry weight (g) } \\
\hline & 2015.1 & 2015.2 & 2016.1 & 2016.2 & 2017.1 & 2017.2 & 2018.1 & 2018.2 & Mean \\
\hline Freedom & $3.26^{\mathrm{ns}}$ & $3.98^{\text {ns }}$ & ----- & $4.79^{n s}$ & $3.98^{\text {ns }}$ & $4.56^{\text {ns }}$ & $4.62 \mathrm{a}$ & $4.40^{\text {ns }}$ & $4.27 a b$ \\
\hline Harmony & 3.41 & 4.11 & $4.26^{\mathrm{ns}}$ & 5.14 & 4.39 & 4.34 & $4.45 \mathrm{ab}$ & 4.70 & $4.41 a$ \\
\hline IAC 313 & 3.03 & 3.87 & 3.82 & 4.99 & 3.95 & 4.09 & $4.19 \mathrm{ab}$ & 4.87 & $4.22 \mathrm{abc}$ \\
\hline IAC 572 & 3.19 & 3.67 & 3.93 & 4.76 & 3.84 & 4.20 & $4.23 a b$ & 4.60 & $4.11 \mathrm{bc}$ \\
\hline IAC 766 & 3.36 & 3.95 & 3.89 & 5.08 & 4.15 & 4.36 & $4.46 a b$ & 4.60 & $4.31 a b$ \\
\hline P1103 & 2.74 & ----- & 3.89 & 4.48 & 3.93 & 4.31 & $4.09 \mathrm{~b}$ & 4.23 & $4.01 \mathrm{c}$ \\
\hline SO4 & 2.74 & ----- & ----- & 4.40 & 4.15 & 4.70 & $4.12 \mathrm{~b}$ & 4.35 & $4.12 b c$ \\
\hline Mean & 3.11 & 3.92 & 3.96 & 4.81 & 4.05 & 4.36 & 4.31 & 8.83 & 4.21 \\
\hline \multirow[t]{2}{*}{ CV (\%) } & 10.42 & 7.98 & 7.67 & 7.75 & 7.54 & 6.57 & 4.91 & 4.53 & 2.52 \\
\hline & \multicolumn{9}{|c|}{ Berry diameter $(\mathrm{mm})$} \\
\hline Freedom & $16.12^{\text {ns }}$ & $17.71^{\mathrm{ns}}$ & ----- & $18.46^{\mathrm{ns}}$ & $17.48^{\text {ns }}$ & $17.68^{\text {ns }}$ & $17.89^{\text {ns }}$ & $19.68^{\text {ns }}$ & 17.63ab \\
\hline Harmony & 16.18 & 17.71 & $17.86^{\text {ns }}$ & 18.60 & 17.59 & 17.70 & 17.74 & 19.48 & $17.75 a$ \\
\hline IAC 313 & 15.63 & 17.02 & ----- & 18.17 & 17.08 & 17.21 & 17.80 & 19.50 & 17.43abc \\
\hline IAC 572 & 15.90 & 17.33 & 17.23 & 18.04 & 16.69 & 17.62 & 17.89 & 19.70 & $17.37 \mathrm{bc}$ \\
\hline IAC 766 & 16.19 & 17.67 & 17.21 & 18.29 & 17.24 & 17.08 & 17.92 & 19.58 & $17.50 \mathrm{abc}$ \\
\hline P1103 & 14.93 & ----- & 17.26 & 17.89 & 17.11 & 17.13 & 17.46 & 19.45 & $17.17 c$ \\
\hline SO4 & 14.80 & ----- & 17.05 & 17.69 & 17.42 & 17.85 & 17.43 & 19.40 & $17.23 c$ \\
\hline Mean & 15.68 & 17.49 & 17.32 & 18.16 & 17.23 & 17.46 & 17.73 & 19.54 & 17.44 \\
\hline CV (\%) & 4.45 & 3.09 & 4.20 & 2.52 & 2.43 & 2.72 & 1.76 & 2.76 & 0.93 \\
\hline
\end{tabular}


Table 2: Continuation.

\begin{tabular}{|c|c|c|c|c|c|c|c|c|c|}
\hline \multirow{3}{*}{ Rootstocks } & \multicolumn{9}{|c|}{ Growing seasons } \\
\hline & \multicolumn{9}{|c|}{ Soluble solids ( $\left.{ }^{\circ} \mathrm{Brix}\right)$} \\
\hline & 2015.1 & 2015.2 & 2016.1 & 2016.2 & 2017.1 & 2017.2 & 2018.1 & 2018.2 & Mean \\
\hline Freedom & $19.20^{\text {ns }}$ & $22.73^{\text {ns }}$ & +---- & $20.54^{\text {ns }}$ & $19.43^{\text {ns }}$ & $16.79 a b$ & $18.41^{\text {ns }}$ & $19.10^{\text {ns }}$ & $19.99 a$ \\
\hline Harmony & 18.63 & 20.97 & $16.18^{\text {ns }}$ & 20.95 & 17.23 & $15.26 \mathrm{~b}$ & 18.91 & 19.35 & $18.49 b$ \\
\hline IAC 313 & 19.53 & 21.20 & ---- & 21.10 & 17.25 & $18.99 \mathrm{a}$ & 18.49 & 18.60 & $19.76 a$ \\
\hline IAC 572 & 20.63 & 22.30 & 18.67 & 21.90 & 18.48 & $15.96 \mathrm{~b}$ & 18.05 & 17.60 & $19.99 a$ \\
\hline IAC 766 & 18.83 & 21.05 & 17.97 & 21.13 & 17.88 & $16.80 a b$ & 18.39 & 19.60 & $19.37 a b$ \\
\hline P1103 & 20.93 & ----- & 17.20 & 20.48 & 18.50 & $16.78 a b$ & 18.51 & 18.93 & 19.13ab \\
\hline SO4 & 21.10 & ----- & 17.27 & 20.78 & 18.53 & $17.11 \mathrm{ab}$ & 19.40 & 19.20 & $19.84 a$ \\
\hline Mean & 19.84 & 21.65 & 17.46 & 20.98 & 18.18 & 16.81 & 18.59 & 18.91 & 19.51 \\
\hline \multirow[t]{2}{*}{ CV (\%) } & 6.04 & 8.45 & 11.46 & 8.44 & 7.88 & 6.95 & 4.74 & 6.47 & 2.62 \\
\hline & \multicolumn{9}{|c|}{ Titratable acidity $\left(\mathrm{g} 100 \mathrm{~mL}^{-1}\right)$} \\
\hline Freedom & $0.75^{\text {ns }}$ & $0.44^{\text {ns }}$ & ----- & $0.49^{\text {ns }}$ & $0.31^{\mathrm{ns}}$ & $0.60^{3}$ & $0.46^{\mathrm{ns}}$ & $0.33^{\text {ns }}$ & $0.49^{\text {ns }}$ \\
\hline Harmony & 0.72 & 0.46 & $0.49^{\text {ns }}$ & 0.57 & 0.29 & 0.72 & 0.44 & 0.39 & 0.52 \\
\hline IAC 313 & 0.74 & 0.50 & ----- & 0.54 & 0.28 & 0.67 & 0.49 & 0.35 & 0.51 \\
\hline IAC 572 & 0.79 & 0.52 & 0.54 & 0.57 & 0.32 & 0.71 & 0.48 & 0.42 & 0.54 \\
\hline IAC 766 & 0.76 & 0.39 & 0.43 & 0.47 & 0.26 & 0.53 & 0.57 & 0.40 & 0.47 \\
\hline P1103 & 0.73 & ---- & 0.52 & 0.60 & 0.30 & 0.84 & 0.47 & 0.38 & 0.57 \\
\hline SO4 & 0.68 & ----- & 0.49 & 0.55 & 0.31 & 0.67 & 0.50 & 0.45 & 0.53 \\
\hline Mean & 0.74 & 0.46 & 0.49 & 0.54 & 0.30 & 0.68 & 0.49 & 0.39 & 0.52 \\
\hline CV (\%) & 8.49 & 17.17 & 15.35 & 10.52 & 13.95 & ----- & 20.90 & 22.89 & 8.82 \\
\hline
\end{tabular}

${ }^{1}$ Mean values followed by the same lowercase letter in the column do not differ by the Tukey test at the level of $5 \%$ probability; ${ }^{2}$ ns: not significant; ${ }^{3}$ analysis of variance was not performed because the data did not exhibit normal distribution.

The mean values for soluble solids content (SS) among rootstocks ranged from $18.49^{\circ} \mathrm{Brix}$ ('Harmony') to $19.99{ }^{\circ}$ Brix ('Freedom' and 'IAC 572'), which is in accordance with the SS suggested by Maia et al. (2014) for the harvest of 'BRS Vitória', as well as with the results obtained in preliminary studies already conducted in this same region (Leão; Lima, 2016). In relation to titratable acidity (TA), there was no effect of the rootstock, observing variations among the production cycles from $0.30 \mathrm{~g}$ tartaric acid $100 \mathrm{~mL}^{-1}$ (5th cycle) to $0.74 \mathrm{~g}$ tartaric acid $100 \mathrm{~mL}^{-1}$ (1st cycle). In most of the cycles, the TA values were below those observed for 'BRS Vitória' in the Vale do São Francisco (Leão; Lima, 2016).

As expected, seasonal climate changes resulted in variations in soluble solids content and titratable acidity among the production cycles, reaching maximum values of around $21^{\circ}$ Brix and TA of 0.46 and $0.54 \mathrm{~g} 100 \mathrm{~mL}^{-1}$ in the crop seasons of the second semester of 2015 and 2016 (Table 2), whose periods of grape ripening coincided with months of temperatures higher than those observed in the other cycles (Figure 1).

In Table 2, a significant reduction in the values of SS can be observed in the grapevines grafted on 'Harmony' compared to 'Freedom', 'IAC 313', 'IAC 572', and 'SO4'. The effect of the rootstock on chemical composition of the grape, especially SS and TA, show conflicting results in the literature, which vary in accordance with the rootstock and canopy combination, but they also depend on the effects of the rootstock on fruit production and development, which are affected by other factors, such as vineyard management and seasonal climate variations (Zhang et al., 2016). 


\section{CONCLUSIONS}

Rootstocks had little effect on yield and the physical and chemical characteristics of the 'BRS Vitória' grapes over the eight production cycles evaluated in this study. 'Harmony' rootstock promoted greater berry mass and diameter but reduced the soluble solids content. Vines of 'BRS Vitória' showed moderate vigor, high bud fertility and yield, satisfactory characteristics of bunch and berry, sugars and acids content that meet the requirements of the most demanding markets in all the rootstocks evaluated in this study.

\section{REFERENCES}

ALY, M. A. et al. Performance of some table grape cultivars grafting on different rootstocks in El-Nubaria region. Asian Journal of Crop Science, 7(4):256-266, 2015.

ASSOCIATION OF OFFICIAL AGRICULTURAL CHEMISTS. Official methods of analysis of the association of the agricultural chemists. 18. ed. Gaithersburg: AOAC. 1025p. 2010.

BASCUNÁN-GODOYA, L. et al. Rootstock effect on irrigated grapevine yield under arid climate conditions are explained by changes in traits related to light absorption of the scion. Scientia Horticulturae, 218:284-292, 2017.

CHOU, N. Y.; LI, K. T. Rootstock and seasonal variations affect anthocyanin accumulation and quality traits of 'Kyoho' grape berries in subtropical double cropping system. Vitis, 53(4):193-199, 2014.

CHRISTENSEN, L. P. et al. Wine grape varieties in california. University of California, 188p, 2003.

FELDBERG, N. P.; REGINA, M. A. de; DIAS, M. S. C. Desempenho agronômico das videiras 'Crimson Seedless' e 'Superior Seedless' no norte de Minas Gerais. Pesquisa Agropecuária Brasileira, 42(6):777-783, 2007.

IBACACHE, A.; ALBORNOZ, F.; ZURITA-SILVA, A. Yield responses in flame seedless, Thompson seedless and red globe table grape cultivars are differentially modified by rootstocks under semi arid conditions. Scientia Horticulturae, 204:25-32, 2016.

JIN, Z. X. et al. Modifications of 'Summer Black' grape berry quality as affected by the different rootstocks. Scientia Horticulturae, 210:130-137, 2016.

KOUNDOURAS, S. et al. Rootstock effects on the adaptive strategies of grapevine (Vitis vinifera L. cv. Cabernet Sauvignon) under contrasting water status: Leaf physiological and structural responses. Agriculture, Ecosystems \& Environment, 128(1-2):86-96, 2008.
LEÃO, P. C. S. de; BRANDÃO, E. O.; GONCALVES, N. P. da S. Production and quality of table grapes Sugraone on different rootstocks in the São Francisco Valley. Ciência Rural, 41(9):1526-1531, 2011.

LEÃO, P. C. S. de; LIMA, M. A. C. de. Uva de mesa sem sementes 'BRS Vitória': Comportamento agronômico e qualidade dos frutos no Submédio do Vale do São Francisco. Embrapa Semiárido: Petrolina. Comunicado Técnico, 168. 5p. 2016.

LEÃO, P. C. S. de; SILVA, D. J. Cultivo da videira no semiárido nordestino. In: PIO, R. Cultivo de fruteiras de clima temperado em regiões subtropicais e tropicais. 2. ed. rev. e ampl. Lavras: Ed. UFLA, p.586-625. 2018.

LEÃO, P. C. S. de. et al. Bud fertility of new table grape cultivars and breeding selections in the São Francisco Valley. Revista Brasileira de Fruticultura, 39(5):1-8, 2017.

MAIA, J. D. G. et al. 'BRS Vitória': A novel seedless table grape cultivar exhibiting special flavor and tolerance to downy mildew (Plasmopara viticola). Crop Breeding and Applied Biotechnology, 14(3):204-206, 2014.

OLLAT, N. et al. Grapevine rootstocks: Origins and perspectives. Acta Horticulturae, 1136:11-22, 2016.

PARANYCHIANAKIS, N. V.; AGGELIDES, S.; ANGELAKIS, A. N. Influence of rootstock, irrigation level and recycled water on growth and yield of Soultanina grapevines. Agricultural Water Management, 69(1):13-27, 2004.

SATISHA, J. et al. Influence of rootstocks on growth yield and fruit composition of Thompson seedless grapes grown in the pune region of India. South African Journal Enology and Viticulture, 31(1):1-8, 2010.

SOUZA, R. T. de et al. Frequency of fungicide application for controlling downy mildew in seedless grape plant "BRS Vitória". Revista Brasileira de Fruticultura, 40(3):1-7, 2018.

VRSIC, S.; PULKO, B.; KOCSIS, L. Factors influencing grafting success and compatibility of grape rootstocks. Scientia Horticulturae, 181:168-173, 2015.

WHITING, J. Rootstock Breeding and Associated R\&D in the Viticulture and Wine Industry, Adelaide, Australia: Grape and Wine Research and Development Corporation. 54p. 2012.

ZHANG, L. et al. The influence of grapevine rootstocks on scion growth and drought resistance. Theoretical and Experimental Plant Physiology, 28:143-157, 2016. 